\title{
Soil and seedling response to dehydrated septic tank sludge versus forest floor additions at a disturbed site
}

\author{
Lili Perreault, Suzanne Brais, Nicolas Bélanger, and Sylvie Quideau
}

\begin{abstract}
Over a period of $2 \mathrm{yr}$, the effects of dehydrated septic tank sludge application on the chemical properties of a severely disturbed forest clayey soil were assessed and compared with application of native forest floor (i.e., from neighboring forest). Six treatments [fresh and mature sludges $\times$ two depths (15 and $25 \mathrm{~cm})$, forest floor, and a control] were replicated three times according to a complete random design. Total organic $\mathrm{C}$ and $\mathrm{N}$ concentrations of amendments and their chemical structure, based on ${ }^{13} \mathrm{C}$ nuclear magnetic resonance (NMR) spectroscopy, were determined. Mineral soil $\mathrm{C}$ and $\mathrm{N}$ concentrations and $\mathrm{C}$ mineralization rates were monitored as well as nutrient supply rates using Plant Root Simulator ${ }^{\mathrm{TM}}$ probes. White spruce [Picea glauca (Moench) Voss] seedling foliar nutrition and growth were also monitored. NMR spectroscopy revealed differences among amendments, with the forest floor spectra displaying lower 0 -alkyl $\mathrm{C}$ and higher alkyl $\mathrm{C}$ and carbonyl $\mathrm{C}$ proportions relative to sludge. Neither soil C concentrations nor mineralization were significantly improved in the mineral soil under any treatment, even at application rates exceeding $700 \mathrm{t}$ sludge ha ${ }^{-1}$ (dry mass). The sludges supplied more $\mathrm{NO}_{3}$ and $\mathrm{P}$, and less $\mathrm{NH}_{4}$ and $\mathrm{K}$ to the mineral soil than the forest floor and control. Increased nutrient availability under sludge and forest floor generally resulted in improved foliar nutrition and growth of white spruce seedlings. Despite differences in organic matter quality and mineral $\mathrm{N}$ form supplied by sludge and forest floor, sludge application is a valid restoration approach.
\end{abstract}

Key words: septic tank sludge, forest soil, macronutrient, nitrification.

Résumé : Pendant deux ans, les auteurs ont évalué les effets de l'application de boue déshydratée de fosse septique sur les propriétés chimiques d'un sol forestier argileux très perturbé et ont comparé ces effets à ceux obtenus avec l'application de sol forestier naturel (venant d'une forêt voisine). Six traitements [boue fraîche et boue mature $\mathrm{x}$ deux profondeurs $(15$ et $25 \mathrm{~cm})$, sol forestier et témoin] ont été reproduits à trois reprises dans un dispositif randomisé. Les auteurs ont déterminé la concentration totale de $\mathrm{C}$ organique et de $\mathrm{N}$ des amendements ainsi que leur structure chimique par spectroscopie à résonance magnétique nucléaire $(\mathrm{RMN})$ au ${ }^{13} \mathrm{C}$. Ils ont surveillé la concentration de $\mathrm{C}$ et de $\mathrm{N}$ dans le sol minéral ainsi que le taux de minéralisation et l'apport d'oligoéléments au moyen de sondes Plant Root Simulator ${ }^{\mathrm{MC}}$. Enfin, ils ont mesuré la nutrition et la croissance des feuilles de plantules de pin blanc [Picea glauca (Moench) Voss]. La spectroscopie RMN révèle des variations entre les amendements, le spectre du sol forestier indiquant une proportion plus faible de C-O-alkyle et des proportions plus élevées de C-alkyle et de C-carbonyle que la boue. Aucun traitement n'a augmenté de manière significative la concentration de $C$ ni la minéralisation dans le sol minéral, même aux taux d'application supérieurs à $700 \mathrm{t}$ de boue par hectare (poids sec). La boue apporte plus de $\mathrm{NO}_{3}$ et de $\mathrm{P}$ au sol minéral que le sol forestier et le sol témoin, mais moins de $\mathrm{NH}_{4}$ et de $\mathrm{K}$. La quantité supérieure d'oligoéléments disponible dans la boue et le sol forestier entraîne généralement une meilleure nutrition et croissance des feuilles chez les plantules de pin blanc. Bien que la qualité de la matière organique et le type de $\mathrm{N}$ minéral fournis par la boue et le sol forestier diffèrent, l'application de boue demeure une approche valable à la restauration des sols. [Traduit par la Rédaction]

Mots-clés : boue de fosse septique, sol forestier, macronutriment, nitrification.

Received 24 June 2017. Accepted 25 October 2017.

L. Perreault and S. Brais. Institut de recherche sur les forêts, Université du Québec en Abitibi-Témiscamingue, 445 boul. Université, Rouyn-Noranda, QC J9X 5E4, Canada.

N. Bélanger. TELUQ 5800, rue Saint-Denis, bureau 1105, Montréal, QC H2S 3L5, Canada.

S. Quideau. Department of Renewable Resources, University of Alberta, 442 Earth Sciences Building, Edmonton, AB T6G 2E3, Canada. Corresponding author: Lili Perreault (email: lili.perreault@uqat.ca).

Abbreviations: $\mathrm{NMR}$, Nuclear Magnetic Resonance, $\mathrm{NO}_{3}{ }^{-}$, nitrate, $\mathrm{PO}_{4}{ }^{3-}$, phosphate, $\mathrm{NH}_{4}$, ammonium.

Copyright remains with the author(s) or their institution(s). Permission for reuse (free in most cases) can be obtained from RightsLink. 


\section{Introduction}

Soil application of sewage sludge is an economical alternative to inorganic fertilizers (Pritchard et al. 2010) and costly landfill disposal (Torri et al. 2014a). This practice is increasing worldwide (Giusti 2009) as a result of more stringent laws regulating water quality, and growing concerns about the environmental impacts of landfills, incineration, and water disposal of these residual materials (Singh and Agrawal 2008).

In the wake of activities that cause severe soil disturbance, such as in mining, site reclamation requires redistribution of the original topsoil over the disturbed area (Sheoran et al. 2010). However, topsoil quality may decrease due to initial stripping and long-term stockpiling (Ghose 2004; Menta et al. 2014), thus hindering soil recovery. In this context, septic tank sludge application could replace surface organic matter and help re-establish soil properties and functions such as $C$ levels, water and nutrient retention and supply capacity, microbial diversity, and ecosystem resilience (Bell 2006).

Several processes supporting forest ecosystem functions and integrity take place within the forest floor (Rydgren and Hestmark 1997), including nutrient and $\mathrm{C}$ retention and cycling (Prescott et al. 2000). In the boreal forest, soils typically have low $\mathrm{N}$ availability (Weetman and Nykvist 1963; Vitousek and Howarth 1991) and the removal of the forest floor has long-lasting consequences on nutrient cycling and retention (Brais et al. 1995). Severely disturbed forest soils following intensive harvesting and site preparation (Fleming et al. 2006) may benefit from the application of sludge due to its high organic matter and nutrient contents (Larney and Angers 2012).

Despite large differences in sludge properties, several studies (Soriano-Disla et al. 2010; Singh et al. 2011; Torri et al. 2014b) have reported short-term (2-3 yr) improvements of nutrient availability in unproductive forest soils after sludge application (Hallett et al. 1999; Bramryd 2002; Cavaleri et al. 2004; Varela et al. 2011). Carbon and $\mathrm{N}$ addition from sludge may benefit soil microbial biomass (Kuzyakov et al. 2000; Singh and Agrawal 2008), which, in turn, increases $C$ and $\mathrm{N}$ mineralization rates (Khan and Scullion 2002; Gibbs et al. 2006; Kao et al. 2006) and the release of other nutrients such as $\mathrm{P}, \mathrm{Ca}$, and $\mathrm{K}$. As a whole, sludge application has been shown to improve tree nutrition and growth from increased soil organic $C$ and nutrient availability (Gaulke et al. 2006; Selivanovskaya and Latypova 2006; Holm and Heinsoo 2013). However, at sludge application rates exceeding vegetation requirements, nitrate $\left(\mathrm{NO}_{3}{ }^{-}\right)$and phosphate $\left(\mathrm{PO}_{4}{ }^{3-}\right)$ can leach below the rooting zone and contaminate groundwater (Samaras et al. 2008) or eventually reach surface waters, thus promoting eutrophication
(Correll 1998). Such problems would be expected in regions receiving heavy rainfall where the nutrient runoff potential is high (Fredriksen et al. 1973; Grey and Henry 2002).

To the best of our knowledge, few studies to date have compared the effects of septic tank sludge application with those of introducing native forest floor to a disturbed soil (Zbytniewski and Buszewski 2005). This comparison could be helpful to evaluate the potential of sludge amendments to restore predisturbance soil properties and ecosystem functions. Given the high sludge application rate of the study and lower $\mathrm{C} / \mathrm{N}$ ratio when compared with native forest floor, we first hypothesized that sludge would increase mineral soil total $\mathrm{C}$ and $\mathrm{N}$ concentrations and $\mathrm{N}, \mathrm{P}$, and $\mathrm{K}$ supply compared with native forest floor or a control (no amendment). Second, increased nutrient availability from sludges would increase tree seedling foliar nutrition and growth in comparison to the forest floor and control treatment.

\section{Materials and Methods}

Study area

The study site was located at the Lake Duparquet Research and Teaching Forest about $45 \mathrm{~km}$ northwest of Rouyn-Noranda, Quebec $\left(48^{\circ} 47^{\prime} \mathrm{N}, 79^{\circ} 44^{\prime} \mathrm{W}\right)$. The region is situated at the southern fringe of the boreal forest and belongs to the balsam fir [Abies balsamea (L.)], white birch (Betula papyrifera Marsh), and white spruce [Picea glauca (Moench) Voss] bioclimatic domain (Robitaille and Saucier 1998). The climate is continental with a mean annual temperature of $0.5{ }^{\circ} \mathrm{C}$ and a mean annual precipitation of $975 \mathrm{~mm}$ (1971-2000; Environnement Canada 2010). Soils (70\% clay content; Agriculture and Agri-Food Canada 2012) at the study site developed on mesic glaciolacustrine clayey deposits left by the Barlow-Ojibway proglacial lake (Veillette et al. 2000) and are classified as Gray Luvisols (Soil Classification Working Group 1998). The MOR forest floor averages $10 \mathrm{~cm}(\mathrm{SE}=0.9)$ in depth.

Prior to harvest, the stand at the study site was dominated by balsam fir, white birch, and white spruce originating from a fire dating from 1760 . Intensive site preparation was undertaken following clear-cut harvesting in 2004 (see full site preparation done prior to planting in Elferjani et al. 2014). Briefly, stumps and woody debris were removed with a bulldozer and piled away from the plantation site. The cleared soil was then tilled and harrowed to a depth of $30 \mathrm{~cm}$ in preparation for planting. In the spring of 2005, hybrid poplars (Populus spp.) were planted in rows located $3 \mathrm{~m}$ apart. In the $3 \mathrm{yr}$ following hybrid poplar establishment, competing vegetation was removed mechanically by harrowing the soil surface among the trees. These operations may have contributed to an increase 
Table 1. Average physical and chemical properties of the mineral topsoil $(0-10 \mathrm{~cm})$ sampled at the study site $(2013)$ and at an undisturbed location from a nearby natural forest stand.

\begin{tabular}{lll}
\hline & Study site & Undisturbed $^{a}$ \\
\hline Bulk density $\left(\mathrm{g} \mathrm{cm}^{-3}\right)$ & $1.09(0.09)$ & $0.85(0.19)$ \\
Total N $\left(\mathrm{mg} \mathrm{g}^{-1}\right)$ & $2.4(0.8)$ & $3.9(2.2)$ \\
Total C $\left(\mathrm{mg} \mathrm{g}^{-1}\right)$ & $29.7(13.8)$ & $57.5(30.3)$ \\
$\mathrm{C} / \mathrm{N}$ & $11.8(2.0)$ & $15.1(2.2)$ \\
Total N concentration & $262(73)$ & $332(184)$ \\
$\quad\left(\mathrm{g} \mathrm{m}^{-2} 10 \mathrm{~cm}^{-1}\right)$ & & \\
Total C content & $3.24(1.34)$ & $4.89(2.45)$ \\
$\quad\left(\mathrm{kg} \mathrm{m}^{-2} 10 \mathrm{~cm}^{-1}\right)$ & & \\
$\mathrm{pH}^{a}$ & 5.89 & 5.09 \\
\hline
\end{tabular}

Note: Mean (SE), $n=15$. Results are presented on a dry soil weight basis.

${ }^{a}$ S. Brais, unpublished data.

in surficial mineral soil bulk density $(+22 \%)$ and decreases of $48 \%$ in total soil C concentrations and $33 \%$ in total C mass (Table 1 ).

\section{Experimental design}

Septic tank sludge used in this study was obtained from the Abitibi-Ouest Regional County Municipality. Upon collection, the sludge was stored in dehydration basins ( $45 \mathrm{~m} \times 40 \mathrm{~m} \times 3 \mathrm{~m}$ ) lined with wood chips until the basin is emptied. The sludge is then piled on the outer edges of the basins. We used a sludge that was extracted from a basin and piled for over $5 \mathrm{yr}$ (mature) and a sludge that was extracted $1 \mathrm{yr}$ before its application (fresh; Table 2). The sludge was screened before application to remove coarse debris.

The sludge was applied on 27 Aug. 2013 at the soil surface and was not mixed in. The experimental design initially consisted of three replications of five treatments (two types of sludge $\times$ two sludge depths and control) applied to 15 randomly distributed $3 \mathrm{~m} \times$ $15 \mathrm{~m}$ experimental plots established among hybrid poplar rows. The treatment loads were designed to reproduce a range of thickness $(5$ and $15 \mathrm{~cm}$ ) that encompassed the average forest floor depth in surrounding natural stands (i.e., $10 \mathrm{~cm}, \mathrm{SE}=0.9$; Brais et al. 2002). However, the resulting treatment depths were higher than the target depths (i.e., 15 and $25 \mathrm{~cm}$, see Table 2 for application rate equivalents and general characteristics). A sixth treatment consisting of a forest floor amendment was applied in May 2014 to three additional and randomly distributed plots. Due to the physical effort involved in collecting forest floor material, these plots were smaller $(3 \mathrm{~m} \times 3 \mathrm{~m})$ than that of other treatments. Forest floor material $(0-10 \mathrm{~cm})$ was collected by hand from a nearby $(<500 \mathrm{~m})$ natural stand similar to the one harvested in 2004 at the study site. Application rate equivalents and general characteristics of the native forest floor are presented in Table 2. Hybrid poplar litter accumulation on the mineral soil was minimal even after $8 \mathrm{yr}$ and was not removed before sludge and forest floor application.

In June of 2014, 241 white spruce seedlings were planted in all 18 plots and numbered. Fifteen seedlings were planted in two rows in each of the $3 \mathrm{~m} \times 15 \mathrm{~m}$ plots where sludge was applied. To maintain a similar spacing among seedlings, only four seedlings were planted in each of the $3 \mathrm{~m} \times 3 \mathrm{~m}$ plots where the native forest floor was added.

\section{Field sampling}

Sampling in $3 \mathrm{~m} \times 15 \mathrm{~m}$ plots was done at 1, 7.5, and $14 \mathrm{~m}$ from the plot end lengthwise. In $3 \mathrm{~m} \times 3 \mathrm{~m}$ plots, sampling was done $1 \mathrm{~m}$ apart from the plot edge in a clockwise direction at intervals of $1 \mathrm{~m}$, providing a total of three sampling locations in each plot. Sampling described below applies to these three locations.

Organic amendments (sludge and native forest floor) from each plot were collected at $0-10 \mathrm{~cm}$ for organic C and total $\mathrm{N}$ in the spring of 2014 and 2015, and for bulk composition (i.e., $\mathrm{P}, \mathrm{K}, \mathrm{Ca}, \mathrm{Mg}, \mathrm{Al}, \mathrm{Cu}, \mathrm{Zn}$, and $\mathrm{Pb}$ ) analysis in the spring of 2014. Sampling locations were moved slightly to avoid any previous sampling effects. In the spring of 2015, one sample was randomly selected from each amendment type (i.e., fresh sludge, mature sludge, and native forest floor) for nuclear magnetic resonance (NMR) spectroscopy analysis. Mineral soil samples were collected at $0-5 \mathrm{~cm}$ from each plot at the same location as organic samples in the spring of 2015 for $\mathrm{C}$, total $\mathrm{N}$, and microbial respiration analysis.

Ion-exchange resins (i.e., $\mathrm{PRS}^{\mathrm{TM}}$ probes, Western $\mathrm{Ag}$ Innovations, Saskatoon, SK, Canada) were used to assess the soil solution ionic activity $\left(\mathrm{NO}_{3}{ }^{-}-\mathrm{N}, \mathrm{NH}_{4}{ }^{+}-\mathrm{N}\right.$, $\mathrm{H}_{2} \mathrm{PO}_{4}{ }^{-}-\mathrm{P}, \mathrm{K}^{+}$). The $\mathrm{PRS}^{\mathrm{TM}}$ probes allow for a dynamic measurement of ions flowing through the soil over time, and have been frequently used for forest ecology research (Moukoumi et al. 2012; Bilodeau-Gauthier et al. 2013). In each plot, three anion and three cation $\mathrm{PRS}^{\mathrm{TM}}$ probes were inserted vertically using a soil knife in the mineral soil surface $(0-5 \mathrm{~cm}$ depth) directly under the amendment. To do so, the amendment was carefully removed and placed back. The probes were left in the soil for $4 \mathrm{wk}$ periods each time in the fall of 2013 , spring of 2014, fall of 2014, and spring of 2015. Forest floor plots were not sampled in the fall of 2013 as they were only established in 2014. Upon collection, excess soil was removed from the probes with a knife. Cation and anion probes from each plot were placed in a single bag. Probes were brought back to the laboratory where they were immediately cleaned with deionized water and placed in clean bags in a cooler and sent to Western Ag Innovations laboratories for analysis. 
Table 2. Initial sludge and native forest floor characteristics and application rates.

\begin{tabular}{|c|c|c|c|c|c|}
\hline \multirow[b]{2}{*}{ Parameter } & \multicolumn{2}{|l|}{ Fresh sludge (FS) } & \multicolumn{2}{|c|}{ Mature sludge (MS) } & \multirow[b]{2}{*}{ Forest floor $(\mathrm{FF})$} \\
\hline & FS@15 cm & FS@25 cm & MS@15 cm & MS@25 cm & \\
\hline Total C $\left(\mathrm{g} \mathrm{kg}^{-1}\right)$ & $96(4)$ & - & $78(4)$ & - & $427(8)$ \\
\hline Total $\mathrm{N}\left(\mathrm{g} \mathrm{kg}^{-1}\right)$ & $7.5(0.2)$ & - & $5.4(0.2)$ & - & $18(1)$ \\
\hline $\mathrm{C} / \mathrm{N}$ & $12(0)$ & - & $14(0)$ & - & $23(1)$ \\
\hline $\mathrm{pH}\left(\mathrm{H}_{2} \mathrm{O}\right)$ & $7.2(0.1)$ & - & $6.7(0.1)$ & - & $5.3(0.1)$ \\
\hline Minimum & 7.0 & 19 & 11 & 14 & 3.0 \\
\hline Maximum & 27 & 30 & 15 & 26 & 12 \\
\hline Average application rate $\left(\mathrm{kg} \mathrm{ha}^{-1}\right)$ & $702000(123000)$ & $1043000(68000)$ & $818000(26000)$ & $1333000(67000)$ & $10400(900)$ \\
\hline $\mathrm{N}\left(\mathrm{kg} \mathrm{ha}^{-1}\right)$ & $2600(360)$ & $3860(360)$ & $3190(380)$ & $5200(380)$ & $190(20)$ \\
\hline $\mathrm{C}\left(\mathrm{kg} \mathrm{ha}^{-1}\right)$ & $33600(5900)$ & $49900(3300)$ & $42200(1300)$ & $68800(3400)$ & $4500(380)$ \\
\hline $\mathrm{SiO}_{2}\left(\mathrm{~kg} \mathrm{ha}^{-1}\right)$ & \multicolumn{2}{|c|}{$443000(15000)$} & \multicolumn{2}{|c|}{$450000(15000)$} & - \\
\hline
\end{tabular}

Note: Mean (SE). Results are presented on a dry soil weight basis.

Results are reported in micrograms of nutrient adsorbed per membrane surface area $\left(10 \mathrm{~cm}^{2}\right)$ over a given burial time, and are an indication of nutrient supply rate to a plant over the burial time period (Western Ag Innovations Inc. 2010).

Total height, height increment, and root collar diameter were measured in October of 2014 and again in August 2015. Relative growth for 2015 was calculated by dividing yearly height growth (centimetre) measured in 2015 by total height (centimetre) measured in 2014. In October of 2014 and August of 2015, needles were collected from current year needle cohort from four to five (depending on seedling size) randomly selected seedlings in each plot. Needles were then pooled within each plot for foliar nutrient analyses.

\section{Laboratory analysis}

Upon collection, organic amendments and mineral soil samples were placed in a refrigerator $\left(4^{\circ} \mathrm{C}\right)$ pending analyses. Analyses of fresh samples were done within $7 \mathrm{~d}$ of collection. For each fresh sample, a subsample was weighed and oven-dried (at $65{ }^{\circ} \mathrm{C}$ for amendments and $105^{\circ} \mathrm{C}$ for mineral soil samples) for $48 \mathrm{~h}$ to calculate moisture content and sample dry weight (grams).

\section{Bulk chemical composition}

Subsamples of organic amendments and mineral soils were air-dried, sieved at $2 \mathrm{~mm}$ and finely ground for total $\mathrm{N}$ and organic $\mathrm{C}$ analysis (Bremner 1996). Carbon and $\mathrm{N}$ concentrations were then determined on these samples by combustion and thermal conductivity detection using a EA1108 CHNS-O Analyzer (Thermo Fisons, MA, USA).

Bulk composition (P, K, Ca, $\mathrm{Mg}, \mathrm{Al}, \mathrm{Cu}, \mathrm{Zn}$, and $\mathrm{Pb}$ ) of organic amendments was determined by X-ray fluorescence spectrometry using a S8 Tiger WD XRF (Bruker, Billerica, MA, USA) equipped with a high-intensity X-ray tube operating at $4 \mathrm{~kW}$. The fused beads were prepared from a 1:10 soil:1ithium tetra (meta)borate mixture which was heated for $18 \mathrm{~min}$ at $1000{ }^{\circ} \mathrm{C}$.

\section{NMR shift regions}

One representative sample from each amendment type (i.e., fresh sludge, mature sludge, and native forest floor) was air-dried, sieved ( $2 \mathrm{~mm})$, ground, and packed into Bruker $4 \mathrm{~mm}$ thin-walled rotors. Solid-state ${ }^{13} \mathrm{C}$ cross-polarization with magic angle spinning (CP-MAS) NMR spectra was acquired using a Bruker Avance 300 spectrometer $\left[\mathrm{B}_{0}=7.05 \mathrm{~T}, \nu \mathrm{L}\left({ }^{13} \mathrm{C}\right)=75.5 \mathrm{MHz}\right]$. Spectra were acquired using the following parameters: $1 \mathrm{H} 90^{\circ}$ pulse length of $4 \mu \mathrm{s}$, a cross-polarization contact time of $1 \mathrm{~ms}$, acquisition time of $25.6 \mathrm{~ms}$, spinning rate of $10 \mathrm{kHz}$, and a recycle delay of $5 \mathrm{~s}$. A line-broadening factor of $100 \mathrm{~Hz}$ was applied to the three spectra. ${ }^{13} \mathrm{C} \mathrm{NMR}$ spectra were referenced to tetramethylsilane at $0 \mathrm{ppm}$ using adamantane as an external reference (38.56 ppm). Bruker's TopSpin ${ }^{\mathrm{TM}}$ package for NMR data analysis was used to estimate the integrated areas for the following chemical shift regions based on spectra minima: (1) alkyl (0-42 ppm), (2) N-alkyl/methoxy (42-60 ppm), (3) 0-alkyl (60-95 ppm), (4) di-alkyl (95-110 ppm), (5) aromatic (110-140 ppm), (6) phenolic (140-165 ppm), and (7) carbonyl (165-210 ppm). Relative abundance was calculated by dividing the area under the curve for a given chemical shift region by the total area under the curve (0-210 ppm).

\section{Microbial respiration}

Respiration of mineral soils was measured by the soda lime method (Monteith et al. 1964; Edwards 1982; Zilbilske 1994) as modified by Keith and Wong (2006). Fresh samples (300-400 g) were incubated for $24 \mathrm{~h}$ at a constant temperature $\left(18.5^{\circ} \mathrm{C}\right)$ in sealed polyethylene 
containers (14 cm in height and $9 \mathrm{~cm}$ in diameter) with dried and weighed soda lime granules placed in opentopped glass jars. The samples were left at field moisture content and minimally mixed prior to incubation to avoid disturbing the soil or organic matter. Subsequently, soda lime granules were oven-dried at $105{ }^{\circ} \mathrm{C}$ for $14 \mathrm{~h}$ and weighed again. To account for $\mathrm{CO}_{2}$ absorbed by the soda lime granules due to leakage from polyethylene containers during the incubation, blank measurements were made in nine empty sealed polyethylene containers in which soda lime was placed. Mineralized carbon $\left[\mathrm{CO}_{2}(\mathrm{~g})\right]$ over a $24 \mathrm{~h}$ period was estimated using the following equation (Keith and Wong 2006):
(1)

$$
\begin{aligned}
\text { Soil } \mathrm{CO}_{2} \text { efflux }\left(\mathrm{g} \mathrm{C} \mathrm{m}^{-2} \mathrm{~d}^{-1}\right)=\left\{\frac{[(\text { sample weight gain }(\mathrm{g})-\text { mean blank weight gain }(\mathrm{g})) \times 1.69]}{\text { chamber area }\left(\mathrm{m}^{2}\right)}\right\} \\
\times\left[\frac{24(\mathrm{~h})}{\text { duration of exposure }(\mathrm{h})}\right] \times\left[\frac{12}{44}\right]
\end{aligned}
$$

\section{Soil nutrient and trace-metal supplies}

$\mathrm{PRS}^{\mathrm{TM}}$ probes were eluted using a $0.5 \mathrm{~mol} \mathrm{~L}^{-1} \mathrm{HCl}$ solution. Ammonium $\left(\mathrm{NH}_{4}\right)$ and $\mathrm{NO}_{3}$ concentrations were determined colorimetrically with an automated flow injection analysis system, whereas all other ions were analyzed using inductively coupled plasma mass spectrometry (Western Ag Innovations Inc. 2010).

\section{Seedling foliar nutrients}

White spruce needles were oven-dried at $40{ }^{\circ} \mathrm{C}$ to a constant weight and finely ground. Total $\mathrm{N}$ and $\mathrm{C}$ concentrations were determined with the EA1108 CHNS-O Analyzer. Ground samples were also digested with concentrated $\mathrm{HNO}_{3}$ to determine $\mathrm{K}$ concentrations using atomic absorption spectroscopy (model AA-1475, Varian, Palo Alta, CA, USA), whereas $P$ was analyzed colorimetrically (molybdate-based method) using the QuickChem 8500 series 2 FIA system.

\section{Statistical analysis}

Data were analyzed according to a completely random experimental design. Linear mixed models with random effects were used to account for subsampling at the plot scale (random effect). Variance estimates were based on the maximum likelihood and significance of treatment effects on the Type 1 test of hypothesis. Most samplings were done only once or twice over time and at different times of the year. Consequently, analyses were conducted for each sampling period individually instead of being treated as repeated measures. Mean comparison using a priori contrasts was conducted among treatments (control, fresh sludge, mature sludge, and forest floor) and amendment depth (15 vs. $25 \mathrm{~cm}$ ) in sludgeamended plots. Amendment depth was eventually removed as an explanatory factor because it had no significant effect $(p<0.05)$ on soil properties and contributed little to their variation or to overall variance.

A priori contrasts $(\mathrm{df}=3)$ used to test for significantly different properties between organic amendments were (1) forest floor versus sludge amendments, and (2) fresh sludge versus mature sludge. A priori contrasts $(\mathrm{df}=4)$ were also used to assess whether there was a significant difference in properties between mineral soils under (1) control versus sludge amendments, (2) forest floor versus sludge amendments, and (3) fresh sludge versus mature sludge. Since the forest floor plots were established in the spring of 2014 ( $\mathrm{df}=3$ ), contrasts pertaining to fall of 2013 were (1) control versus sludge amendments, and (2) fresh sludge versus mature sludge.

Normality and equal variance were assessed for each variable using the Anderson-Darling test for normality $(p<0.05)$ and graphical tools (QQ plot, distribution of residuals). Data were log-transformed when required. Response variables (i.e., soil properties, nutrient supply, seedling growth, and nutrient foliar concentrations) were analyzed with the $\mathrm{R}$ freeware (R Core Team 2015) using the nlme (linear and nonlinear mixed-effects models) and the gmodels (various R programming tools for model fitting) packages.

\section{Results}

Organic amendments

\section{Bulk chemical composition}

For the duration of the experiment, total carbon $\left(C_{t}\right)$ and total nitrogen $\left(\mathrm{N}_{\mathrm{t}}\right)$ concentrations as well as $\mathrm{C} / \mathrm{N}$ ratios remained significantly higher $(p<0.001)$ in the forest floor than in sludge. Total $C$ concentrations ranged from 397 to $415 \mathrm{mg} \mathrm{g}^{-1}$ in the forest floor material and from 74.1 to $113 \mathrm{mg} \mathrm{g}^{-1}$ in the sludge, whereas $\mathrm{N}_{\mathrm{t}}$ concentrations varied from 15.6 to $18.6 \mathrm{mg} \mathrm{g}^{-1}$ in the forest floor and from 4.4 to $7.5 \mathrm{mg} \mathrm{g}^{-1}$ in the sludge (Table 3 ). Differences among sludge types were found for total C in 2015 and total $\mathrm{N}$ in 2014 and 2015, with significantly higher $(p<0.001)$ concentrations in fresh than in mature sludge. No other significant differences in element concentrations were found between fresh and mature sludges.

Comparing forest floor and sludge further, total P concentrations and $\mathrm{Mg}$ concentrations were higher $(p<0.050)$ in sludge than in the forest floor (Table 3). In 
Table 3. Native forest floor $(0-10 \mathrm{~cm})$ and municipal sewage sludge $(0-10 \mathrm{~cm})$ bulk chemical composition measured in 2014 and 2015.

\begin{tabular}{|c|c|c|c|c|c|c|}
\hline \multirow[b]{2}{*}{ Parameter } & \multicolumn{3}{|c|}{ Treatment means } & \multicolumn{2}{|c|}{ Contrasts } & \multirow{2}{*}{$\begin{array}{l}\text { Maximum value } \\
\left(\mathrm{mg} \mathrm{kg}^{-1}\right)\end{array}$} \\
\hline & $\mathrm{FF}$ & FS & MS & FF vs. $S$ & FS vs. MS & \\
\hline \multicolumn{7}{|c|}{ Total C $\left(\mathrm{mg} \mathrm{g}^{-1}\right)$} \\
\hline 2014 & $415(9)$ & $98.0(6.6)$ & $86.0(6.6)$ & $* * *$ & NS & - \\
\hline 2015 & $397(8)$ & $113(5)$ & $74.1(5.3)$ & *** & *** & - \\
\hline \multicolumn{7}{|c|}{ Total $\mathrm{N}\left(\mathrm{mg} \mathrm{g}^{-1}\right)$} \\
\hline 2014 & $18.6(0.1)$ & $7.50(0.41)$ & $5.78(0.41)$ & $* * *$ & $* * *$ & - \\
\hline 2015 & $15.6(0.3)$ & $6.61(0.24)$ & $4.36(0.24)$ & *** & *** & - \\
\hline \multicolumn{7}{|l|}{$\mathrm{C} / \mathrm{N}$} \\
\hline 2014 & $22.6(0.9)$ & $12.9(0.3)$ & $14.7(0.4)$ & *** & * & - \\
\hline 2015 & $25.6(0.6)$ & $17.0(0.4)$ & $16.8(0.5)$ & *** & NS & - \\
\hline \multicolumn{7}{|c|}{ Phosphorus ( $\mathrm{mg} \mathrm{kg}^{-1}$ ) } \\
\hline 2014 & $674(527)$ & $2116(304)$ & $1743(304)$ & * & NS & - \\
\hline \multicolumn{7}{|c|}{ Potassium $\left(\mathrm{mg} \mathrm{kg}^{-1}\right)$} \\
\hline 2014 & $973(121)$ & $574(70)$ & $447(70)$ & ** & NS & - \\
\hline \multicolumn{7}{|c|}{ Calcium (mg kg-1) } \\
\hline 2014 & $17684(2312)$ & $6295(1335)$ & $6504(1335)$ & $* * *$ & NS & - \\
\hline \multicolumn{7}{|c|}{ Magnesium $\left(\mathrm{mg} \mathrm{kg}^{-1}\right)$} \\
\hline 2014 & $1580(360)$ & $2700(208)$ & $2395(208)$ & * & NS & - \\
\hline \multicolumn{7}{|c|}{ Aluminum $\left(\mathrm{mg} \mathrm{kg}^{-1}\right)$} \\
\hline 2014 & $2152(766)$ & $7112(442)$ & $6015(442)$ & $* * *$ & NS & - \\
\hline \multicolumn{7}{|c|}{ Copper $\left(\mathrm{mg} \mathrm{kg}^{-1}\right)$} \\
\hline 2014 & $50.3(39)$ & $165(23)$ & $135(23)$ & $*$ & NS & 1000 \\
\hline \multicolumn{7}{|c|}{ Zinc ( $\left.\mathrm{mg} \mathrm{kg}^{-1}\right)$} \\
\hline 2014 & $316(95)$ & $402(55)$ & $311(55)$ & NS & NS & 1850 \\
\hline \multicolumn{7}{|c|}{ Lead ( $\left.\mathrm{mg} \mathrm{kg}^{-1}\right)$} \\
\hline 2014 & $64.8(6.4)$ & $48.1(3.7)$ & $41.4(3.7)$ & * & NS & 300 \\
\hline
\end{tabular}

Note: Contrasts between native forest floor (FF) and sludges (S; pooled depth data) and between fresh sludge (FS) and mature sludge (MS) were assessed by means of mixed linear model based on a Type 1 test of hypothesis. Results are presented on a dry soil weight basis. Significant differences are designated as followed: ${ }^{*}, p<0.05$; ${ }^{* *}, p<0.01$; and ***, $p<0.001$, and NS (not significant).

${ }^{a}$ Maximum trace metal limit values allowed in municipal sewage sludge according to legislation of the province of Quebec (MDDEP 2012).

contrast, Ca and $\mathrm{K}$ concentrations were higher $(p<0.010)$ in the forest floor than in the sludge. Concentrations of $\mathrm{Al}$ and $\mathrm{Cu}$ were significantly higher in the sludge than in the forest floor while the reverse was true for $\mathrm{Pb}$. No significant differences among amendment types were found in $\mathrm{Zn}$ concentrations. Trace metal concentrations remained below maximum limit values according to legislation (Table 3; MDDEP 2012).

\section{NMR spectroscopy}

The 0 -alkyl C region of the NMR spectra was the dominant region for all organic amendments (Fig. 1). However, relative abundance of $O$-alkyl $\mathrm{C}$ differed among treatments with the forest floor being the lowest and the fresh sludge being the highest (Table 4). The sharpest peak for all three amendment types was located at $73 \mathrm{ppm}$, which is indicative of polysaccharides making up cellulose and hemicelluloses (Quideau et al. 2001).

The forest floor was richer in alkyl $C$ than both sludges (Table 4). The small peak at $30 \mathrm{ppm}$ observed for the forest floor corresponds to the methylene groups in long-chain aliphatic compounds (KögelKnabner 1997; Bartoszek et al. 2008) found in waxes and cutins, polyesters of roots and bark, condensed tannins and side chains of proteins (Preston 1996). The small peaks in the $20-30 \mathrm{ppm}$ region for the sludges are associated to $\mathrm{C}-\mathrm{CH}_{3}$ moieties (Keeler and Maciel 2000 ), and the sharper peak at 22 ppm likely corresponds to terminal methyl groups of alkyl chains and to acetyl methyl groups in hemicelluloses (Keeler and Maciel 2000). All spectra showed a peak at $56 \mathrm{ppm}$ in the $\mathrm{N}$-alkyl/methoxy $\mathrm{C}$ region which is indicative of $\mathrm{O}-\mathrm{CH}_{3}$ or methoxyl in lignin. 
Fig. 1. Solid-state CP-MAS ${ }^{13} \mathrm{C}$ spectra acquired for the organic amendments: FF (native forest floor); FS (fresh sludge); MS (mature sludge) with seven chemical shifts (ppm) region assigned to the main structural groups. Spectra are superposed for illustrative purposes.

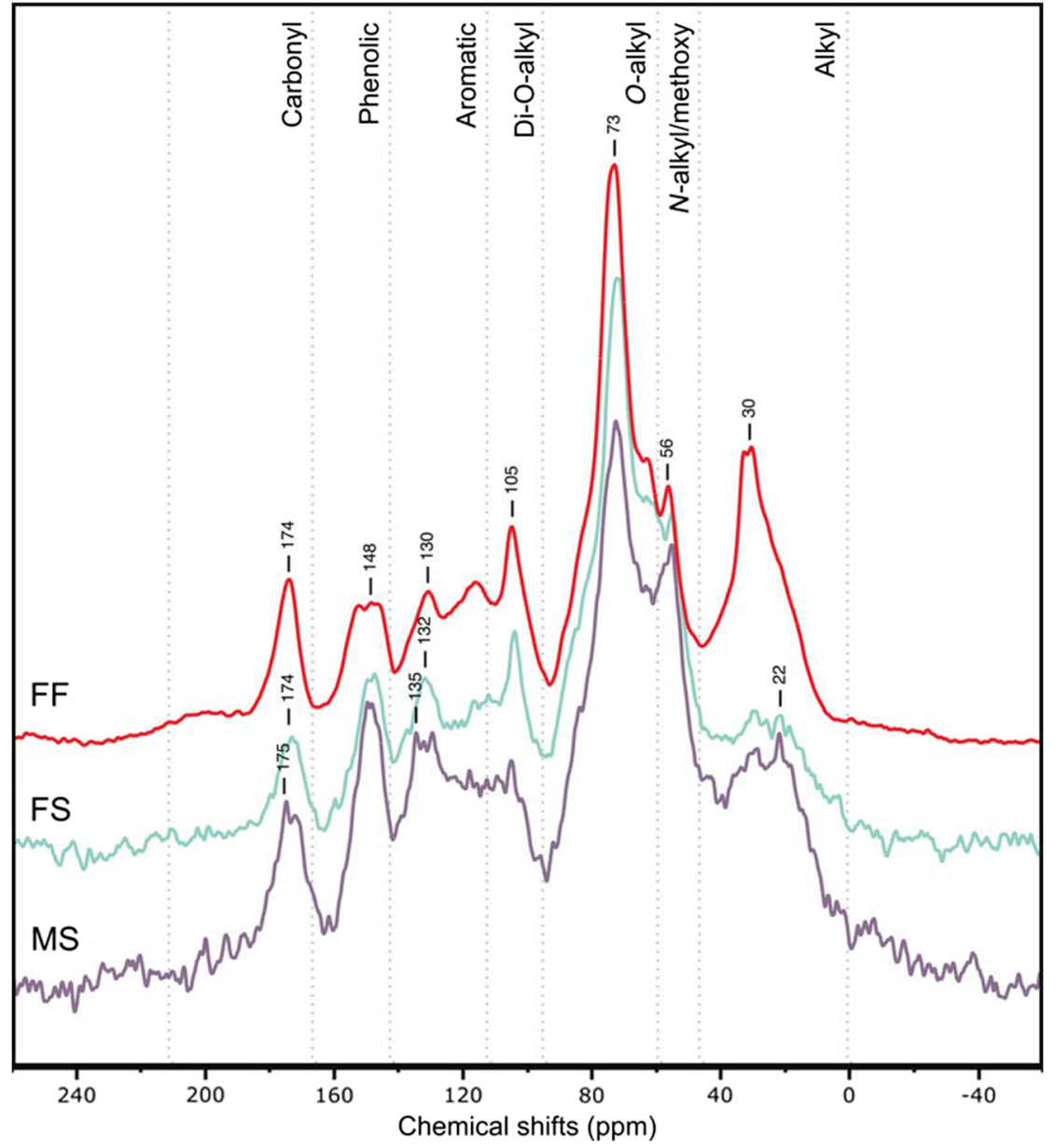

Table 4. Relative abundance (\%) of C structural groups of native forest floor and sludges (\%) measured by solid-state CP-MAS ${ }^{13} \mathrm{C}$ in the spring of 2015.

\begin{tabular}{lccc}
\hline & FF & FS & MS \\
\hline Alkyl & 21.5 & 15.4 & 13.1 \\
N-Alkyl/methoxy & 10.2 & 14.1 & 13.6 \\
O-Alkyl & 32.6 & 37.2 & 35.4 \\
Di-O-alkyl & 7.23 & 7.34 & 7.78 \\
Aromatic & 12.9 & 13.6 & 17.8 \\
Phenolic & 7.57 & 7.68 & 9.77 \\
Carbonyl & 7.94 & 4.69 & 2.69 \\
\hline
\end{tabular}

The mature sludge had the highest abundance of aromatic $C$, with a peak at $135 \mathrm{ppm}$. The relative abundance of phenolic $C$ was also highest in the mature sludge, which was reflected in a higher degree aromaticity (aromatic + phenolic C) compared with the other two materials. Peaks at 148 ppm for all three materials correspond to C3 in guaiacyl units of condensed and hydrolysable tannins and lignins (Preston 1996). Carbonyl C, the most oxidized form of carbon, was highest for the forest floor material (Table 4). Finally, the alkyl:0-alkyl ratio was higher in the forest floor $(0.66)$ and lower in the fresh (0.41) and mature (0.37) sludges.

\section{Mineral soils}

Total carbon, total nitrogen, and microbial respiration

Total $\mathrm{C}, \mathrm{N}_{\mathrm{t}}$ concentrations, and $\mathrm{C} / \mathrm{N}$ ratios were not significantly different below all three amendment types in the spring of 2015 (data not shown). The values obtained for $C_{t}$ ranged from 25.1 to $33.5 \mathrm{mg} \mathrm{g}^{-1}$ and from 1.93 to $2.7 \mathrm{mg} \mathrm{g}^{-1}$ for $\mathrm{N}_{\mathrm{t}}$, whereas the mineral soil $\mathrm{C} / \mathrm{N}$ ratios ranged from 11.8 to 12.0 .

Mineral soil respiration rates per $C$ unit were not significantly different between organic amendments. Rates ranged from 7.9 to $9.7 \mathrm{mg} \mathrm{CO} \mathrm{g} \mathrm{C}^{-1} \mathrm{~d}^{-1}$ in the spring of 2015 (data not shown).

\section{Supply rates (as measured by $\mathrm{PRS}^{\mathrm{TM}}$ probes)}

Immediately following sludge application (i.e., fall of 2013), significant increases in nutrient supply rates 
Fig. 2. Effect of organic amendments on nutrient supply rate $\left(\mu \mathrm{g} 10 \mathrm{~cm}^{-2} 4 \mathrm{wk}^{-1}\right)$ measured with PRS ${ }^{\mathrm{TM}}$ probes at the mineral soil surface $(0-10 \mathrm{~cm})$ for the treatments: control $(\mathrm{C})$, fresh sludge (FS), mature sludge (MS), and native forest floor (FF). The native forest floor (FF) plots were sampled in 2014 and 2015. Data were analyzed by means of a mixed linear model with random effects (plot level) and based on Type 1 hypothesis $(N=18)$.
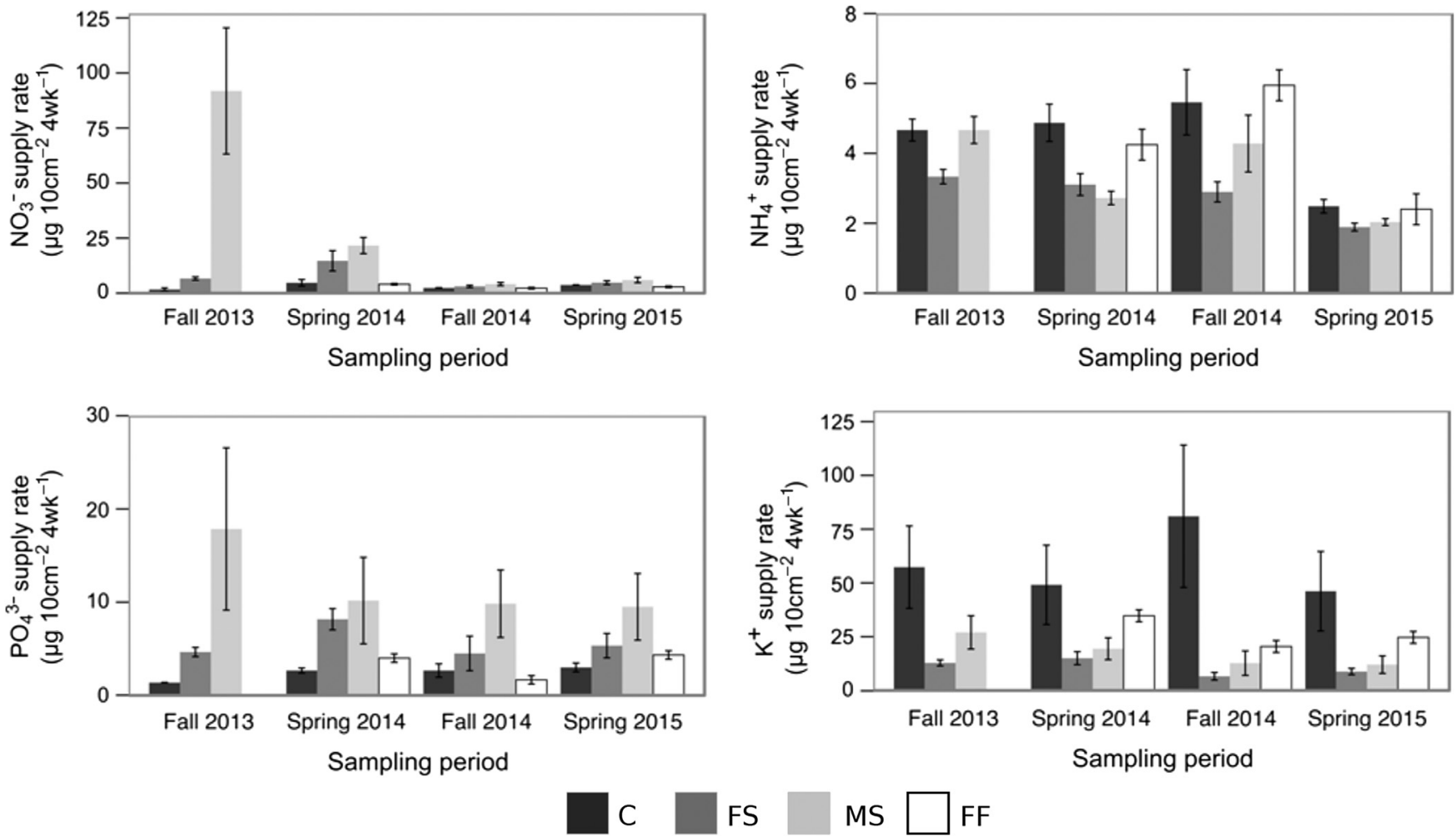

FS

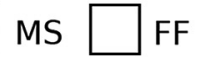

below sludges were observed for $\mathrm{NO}_{3}{ }^{-}$and $\mathrm{PO}_{4}{ }^{3-}$ (Fig. 2; Table 5), whereas $\mathrm{K}^{+}$supply was higher in the control than under the sludges. No difference in supply rates was observed between the control and the sludges for $\mathrm{NH}_{4}^{+}$.

In the spring following amendments, soils under the sludges supplied significantly more $\mathrm{NO}_{3}{ }^{-}$and $\mathrm{PO}_{4}{ }^{3-}$ than the soils under the forest floor and in the control. Soil $\mathrm{NH}_{4}{ }^{+}$supply was higher under the forest floor than under the sludges in the fall of 2014 and higher in the control than under the sludges in the spring of 2015. The supply of $\mathrm{K}^{+}$remained higher for the whole duration of the experiment in the control soils and in soils under the forest floor than in soils receiving the sludges.

\section{Foliar nutrition and seedling growth}

At the end of the first growing season, foliar N, P, and $K$ concentrations of white spruce seedlings were greater under the sludges than in the control (Table 6). Significantly higher foliar N concentrations were observed in the forest floor treatment than in the sludge treatments, whereas no significant difference was found for $\mathrm{P}$ and $\mathrm{K}$. No difference in seedling foliar concentrations was observed between the sludges, except for $\mathrm{K}$ which was higher under the fresh sludge than under the mature sludge.

At the end of the second growing season (i.e., 2015), no differences in $\mathrm{N}$ concentrations were found among treatments. Phosphorus foliar concentrations were significantly greater in the sludge treatments than in the control and forest floor treatments. No differences in $\mathrm{K}$ concentrations were found between control soil and sludge treatments. However, $K$ concentrations were significantly higher under sludges than under the forest floor and higher under mature than under fresh sludge.

Relative growth measured at the end of the second growing season (i.e., 2015) was greater $(p<0.01)$ under the sludges than in the control plots (Table 6). No difference in relative growth rate was observed between the sludges and forest floor or between the fresh sludge and mature sludge.

\section{Discussion}

Chemical characteristics of organic amendments

The dominance of 0 -alkyl groups in sludge amendments indicates a high carbohydrate content, which is in agreement with the findings of several authors for sewage sludges (Rowell et al. 2001; Zbytniewski et al. 2002; 
Table 5. Nutrient supply rates $\left(\mu \mathrm{g} 10 \mathrm{~cm}^{-2} 4 \mathrm{wk}^{-1}\right)^{a}$ of the top mineral soil $(0-10 \mathrm{~cm})$ measured with PRS ${ }^{\mathrm{TM}}$ probes at different periods following organic amendments.

\begin{tabular}{llll}
\hline Sampling & C vs. S & FF vs. S & FS vs. MS \\
\hline Nitrate & & & \\
$\quad$ Fall 2013 & $* *$ & NA & $* * *$ \\
Spring 2014 & ${ }^{b}$ & $* *$ & NS \\
Fall 2014 & NS & NS & NS \\
Spring 2015 & NS & NS & NS \\
Ammonium & & & \\
Fall 2013 & NS & NA & $* *$ \\
Spring 2014 & $* *$ & $*$ & NS \\
Fall 2014 & NS & $*$ & NS \\
Spring 2015 & $*$ & NS & NS \\
Phosphate & & & \\
Fall 2013 & $* *$ & NA & $*$ \\
Spring 2014 & $* *$ & $*$ & NS \\
Fall 2014 & NS & NS & NS \\
Spring 2015 & NS & NS & NS \\
Potassium & & & \\
Fall 2013 & $* *$ & NA & NS \\
Spring 2014 & $*$ & $*$ & NS \\
Fall 2014 & $* *$ & $*$ & $*$ \\
Spring 2015 & $* *$ & $*$ & NS \\
\hline
\end{tabular}

Note: Contrasts between control $(C)$ and sludges $(S$; pooled depth data), between native forest floor (FF) and sludges (S), and between fresh sludge (FS) and mature sludge (MS) were assessed by means of mixed linear model and are based on a Type 1 test of hypothesis. Results are presented on a dry soil weight basis. Significant differences are designated as followed: *, $p<0.05$; **, $p<0.01$; and ${ }^{* * *}, p<0.001$, and NS (not significant). NA is not applicable because the native forest floor material was added in the spring of 2014.

${ }^{a}$ Results are reported in "micrograms of nutrient adsorbed per $10 \mathrm{~cm}^{2}$ of membrane surface over the burial time" and are an indication of "nutrient supply rate to a plant for the duration of the burial" (Western Ag Innovations Inc. 2010).

${ }^{b}$ Log transformed.

Smith et al. 2008). Carbohydrates from fibers are the main component of primary sewage sludge (Jimenez et al. 2013) and include sugars and organic acids that are readily available for uptake by microorganisms (Lessa et al. 1996).

Relative to the sludges, the native forest floor material had a high total $\mathrm{C}$ concentration and $\mathrm{C} / \mathrm{N}$ ratio. Similarly to our findings, Zbytniewski and Buszewski (2005) found the alkyl $C$ and carbonyl $C$ regions of the NMR spectra to be dominant in forest floor material. A higher alkyl C content of the forest floor compared with sludges (Table 4) could have resulted from the residual presence of leaf constituents such as lipids and cutins (KögelKnabner 2002) and microbial products (Miltner et al. 2009), which are generally resistant to decomposition. Moreover, the abundance of carbonyl functional groups has been reported to increase with increasing organic matter humification and decomposition (Bartoszek et al. 2008). In contrast, 0 -alkyl $C$ components typically decrease as a result of decomposition and were found in somewhat higher proportions in the sludges (Baldock et al. 1997; Kögel-Knabner 1997). Furthermore, the alkyl:0-alkyl ratio, which is a measure of the extent of decomposition/humification of a material (Baldock et al. 1997), was higher in the forest floor (0.66) and lower in the fresh (0.41) and mature (0.37) sludges. These findings indicate that the forest floor amendment may be more stable than the sludges, as a result of organic matter humification (Caricasole et al. 2011). Higher stability may be beneficial for soil restoration because nutrient mineralization and subsequent release occurs more slowly, which can translate into longer-lasting effects (Larney and Angers 2012).

\section{Mineral soil total carbon and nitrogen}

Sludge application rates were very high and amounted to net $C$ additions that were 7-14 times higher and $\mathrm{N}$ additions 13-25 times higher than with the forest floor treatment (Table 2), although the forest floor had the highest $\mathrm{N}_{\mathrm{t}}$ concentrations (Table 3 ). Although it was expected that sludge application would increase mineral soil $\mathrm{C}$ and $\mathrm{N}$ concentrations, no difference in mineral soil $\mathrm{C}$ and $\mathrm{N}$ concentrations, and $\mathrm{C}$ mineralization were observed among treatments. The amendments were not mixed into the soil but rather applied at the soil surface which could have delayed the incorporation of $\mathrm{C}$ and $\mathrm{N}$ into the mineral soil. Sludge $\mathrm{C}$ and $\mathrm{N}$ contents were also low compared with other sewage sludge reported in the literature (Epstein 2002; Larney and Angers 2012), in part due to their high silica content (Table 2) and possibly mixing with wood chips lining the dehydration basins. In addition, the high sludge thickness $(>15 \mathrm{~cm})$ may have reduced root establishment, which is an important source of soil organic matter (Singh et al. 2009).

\section{Soil nutrient supply}

As expected, sludge application initially increased the supply of some essential nutrients (i.e., $\mathrm{N}$ and $\mathrm{P}$ ) at the mineral soil surface $(0-5 \mathrm{~cm})$ in comparison to the control and forest floor. However, this effect was of short duration. The nutrient pulse following sludge application is associated with rapid mineralization and transformation of the organic nutrient fraction in the sludge (Epstein 2002). As mentioned above, high 0 -alkyl $\mathrm{C}$ content suggests that sludge provides an important input of labile organic matter for microorganism uptake. However, the nutrient pulse could also indicate rapid release of inorganic soluble $\mathrm{N}$ and $\mathrm{P}$ initially present in the sludge (Moritsuka et al. 2006). The elevated $\mathrm{NO}_{3}{ }^{-}$and $\mathrm{PO}_{4}{ }^{3-}$ supply observed immediately after sludge application (fall of 2013) also reflected high sludge application rates, exceeding $700000 \mathrm{~kg} \mathrm{ha}^{-1}$, 
Table 6. White spruce foliar nutrients and growth response 1 and $2 \mathrm{yr}$ following organic amendments and seedling establishment.

\begin{tabular}{|c|c|c|c|c|c|c|c|}
\hline \multirow[b]{2}{*}{ Parameters } & \multicolumn{4}{|c|}{ Treatment means } & \multicolumn{3}{|c|}{ Contrasts } \\
\hline & $\mathrm{C}$ & FS & MS & $\mathrm{FF}$ & C vs. S & FF vs. S & FS vs. MS \\
\hline \multicolumn{8}{|c|}{ Nitrogen $\left(\mathrm{mg} \mathrm{g}^{-1}\right)$} \\
\hline 2014 & $7.97(0.91)$ & $11.78(0.64)$ & $11.00(0.64)$ & $15.13(0.91)$ & ** & ** & NS \\
\hline 2015 & $2.60(0.08)$ & $2.79(0.05)$ & $2.90(0.05)$ & $2.72(0.08)$ & NS & NS & NS \\
\hline \multicolumn{8}{|c|}{ Phosphorus (mg g ${ }^{-1}$ ) } \\
\hline 2014 & $0.68(0.21)$ & $1.68(0.15)$ & $1.30(0.15)$ & $1.41(0.21)$ & ** & NS & NS \\
\hline 2015 & $1.86(0.26)$ & $2.39(0.11)$ & $2.87(0.11)$ & $1.57(0.15)$ & * & *** & ** \\
\hline \multicolumn{8}{|c|}{ Potassium $\left(\mathrm{mg} \mathrm{g}^{-1}\right)$} \\
\hline 2014 & $1.14(0.43)$ & $4.48(0.30)$ & $2.89(0.30)$ & $3.29(0.43)$ & *** & NS & ** \\
\hline 2015 & $0.24(0.02)$ & $0.19(0.01)$ & $0.26(0.01)$ & $0.17(0.02)$ & NS & $*$ & ** \\
\hline \multicolumn{8}{|c|}{ Yearly height growth $(\mathrm{cm})$} \\
\hline 2014 & $9.24(1.67)$ & $9.73(1.18)$ & $9.34(1.18)$ & $9.05(1.89)$ & NS & NS & NS \\
\hline 2015 & $1.57(1.29)$ & $8.41(0.91)$ & $6.27(0.91)$ & $9.75(1.49)$ & ** & NS & NS \\
\hline \multicolumn{8}{|c|}{ Relative growth ${ }^{a, b}$} \\
\hline 2015 & $0.05(0.06)$ & $0.34(0.04)$ & $0.25(0.04)$ & $0.35(0.07)$ & ** & NS & NS \\
\hline
\end{tabular}

Note: Contrasts between control $(\mathrm{C})$ and sludges $(\mathrm{S})$, between native forest floor $(\mathrm{FF})$ and sludges (S; pooled depth data), and between fresh sludge (FS) and mature sludge (MS) were assessed by means of mixed linear model and are based on a Type 1 test of hypothesis. Results are presented on a dry soil weight basis. Mean (SE). Significant differences are designated as followed: *, $p<0.05$; **, $p<0.01$; and ${ }^{* * *}, p<0.001$, and NS (not significant).

${ }^{a}$ Log transformed.

${ }^{b}$ Relative growth $=$ [height growth $(\mathrm{cm})$ in 2015/total height $(\mathrm{cm})$ in 2014].

compared with rates of $280-500000 \mathrm{~kg} \mathrm{ha}^{-1}$ reported in the literature (Rowell 1996; Harrison et al. 2000; Bramryd 2002; Dumbrell and McGrath 2002; Cavaleri et al. 2004; Varela et al. 2011). However, the two sludge application rates (i.e., 15 and $25 \mathrm{~cm}$ depths) did not differ in regard to nutrient supply rates, which may also reflect some overlap in depth between 15 and $25 \mathrm{~cm}$ application rates.

The forest floor and control supplied more $\mathrm{NH}_{4}{ }^{+}$than $\mathrm{NO}_{3}{ }^{-}$for the duration of the experiment. Nitrification in soils is controlled by $\mathrm{NH}_{4}{ }^{+}$availability and occurs when soil $\mathrm{NH}_{4}{ }^{+}$concentrations exceed plant and microbial uptake (Robertson and Groffman 2015). However, in boreal forest soils, nitrification may be low even under high $\mathrm{NH}_{4}{ }^{+}$availability due to acidic conditions limiting the presence of nitrifiers and hindering nitrification (Ste-Marie and Paré 1999). Relatively high soil $\mathrm{NO}_{3}{ }^{-}$supply rates compared with those of $\mathrm{NH}_{4}^{+}$under the sludges suggest more favourable conditions for nitrification, namely the higher $\mathrm{pH}$ associated with the sludges (Schmidt 1982; Sahrawat 2008) and rapid use of $\mathrm{NH}_{4}{ }^{+}$by nitrifying bacteria.

However, most of the difference in $\mathrm{NO}_{3}{ }^{-}$supply rate among treatments was caused by the high rates observed under the mature sludge. The high soil $\mathrm{NO}_{3}{ }^{-}$ supply rates below the mature sludge when compared with the fresh sludge may be the result of oxygenation of a material that was stored with poor aeration for
5 yr. Manipulations (screening, transport, and spreading) of the material may have induced rapid organic $\mathrm{N}$ mineralization due to increased $\mathrm{O}_{2}$ availability for microbes (Sahrawat 2008). As for composts (Bernal et al. 1998, 2009), a lower $\mathrm{NH}_{4}{ }^{+}$to $\mathrm{NO}_{3}{ }^{-}$ratio may also indicate greater maturity in the mature than fresh sludge. Nonetheless, higher soil $\mathrm{NO}_{3}{ }^{-}$supply rates under sludges were of short duration, and consistent with those reported in other studies (Hallett et al. 1999; Grey and Henry 2002; Robinson et al. 2002; Martínez et al. 2003).

The mature sludge also released high levels of $\mathrm{PO}_{4}{ }^{3-}$ within the top mineral soil in the month following application. Wang et al. (2004) and McLaren et al. (2007) both reported an initial increase in soil $\mathrm{P}$ availability following the application of high loads of digested sludge in Pinus radiata plantations. However, both studies applied sludge to sandy soils, which generally have low sorption capacity (Haynes et al. 2009). Phosphorus leaching is generally limited in acidic $(\mathrm{pH}<5.5)$ and fine-textured forest soils due to retention of $\mathrm{PO}_{4}{ }^{3-}$ by adsorption/ precipitation onto/with amorphous oxides of $\mathrm{Fe}$ and $\mathrm{Al}$ (Johnson et al. 1986) and soil colloids (Haynes et al. 2009). High soil $\mathrm{PO}_{4}{ }^{3-}$ under sludge may therefore be due to saturation from the high application rates, resulting in increased potential for P release (McDowell et al. 2001). Similarly, Islas-Espinoza et al. (2013) found P leaching to increase with application rates in an acidic sandy 
clay loam soil. In their study, the largest P pulse was observed $15 \mathrm{~d}$ after sludge application.

White spruce seedling foliar nutrition and growth

Sludge application improved white spruce seedling growth in the second growing season (2015) in comparison to the control. Increased growth could have resulted from higher soil nutrient availability and improved foliar nutrition observed the previous year (2014). Similarly, Bramryd (2002) reported increased foliar N and $\mathrm{P}$ concentrations in Scots pine (Pinus sylvestris) needles as well as improved growth in the year following the application of $20000 \mathrm{~kg} \mathrm{ha}^{-1}$ of sewage sludge. Moreover, as a result of the thick layer of sludge in the experimental plots, seedlings were rooted mainly in the sludge material and their roots barely reached the mineral soil. As such, the improved growth in white spruce seedlings could also be linked to a greater rooting ability in a softer substrate (i.e., sludge), whereas the dense clayey soil likely hindered root development in the control (DesRochers and Tremblay 2009; Larcheveque et al. 2011).

Contrary to our hypothesis and in spite of overall lower supply of essential nutrients in soils receiving the native forest floor, white spruce seedlings had a yearly growth and foliar nutrient concentrations comparable to those treated with the sludge. These results should be interpreted with care because subsampling was small (i.e., four seedlings being planted in the forest floor plots), but the within-plot variation was also small. Thus, improved growth under the forest floor may be attributed in part to higher soil $\mathrm{NH}_{4}{ }^{+}$supplies than under sludge and in turn, to preferential $\mathrm{NH}_{4}{ }^{+}$assimilation (Kronzucker et al. 1997) by white spruce as observed by the higher foliar $\mathrm{N}$ concentration in 2014 (first year). Moreover, the native forest floor may have enhanced soil nutrient availability to white spruce seedlings, notably $\mathrm{N}$ and $\mathrm{P}$, by allowing for mycorrhizae associations to develop more readily (Smith and Read 2009).

\section{Conclusions}

Dehydrated septic tank sludges enhanced nutrient supply rates and white spruce growth in a disturbed forest soil 2 yr after its application, but had limited effects on mineral soil properties. We hypothesized that the mineral soil $\mathrm{C}$ and $\mathrm{N}$ concentrations, and the supply of $\mathrm{N}, \mathrm{P}$, and $\mathrm{K}$, would be higher under sludge than under the native forest floor. However, both sludge and native forest floor had limited effects on mineral soil properties including $\mathrm{C}$ and $\mathrm{N}$ concentrations. Although rapid nutrient mineralization and release takes place shortly after sludge application, organic matter incorporation and improvement of soil physical conditions may take longer in these fine-textured boreal forest soils. Consequently, long-term effects of sludge application need to be monitored to assess changes in soil $\mathrm{C}$ and $\mathrm{N}$ dynamics and physical properties.
Moreover, our results highlight important differences in the chemical form and concentrations of nutrients released below each amendment type. Nitrate release was very high immediately after sludge application and in the following year, especially below the mature (stored 5 yr) sludge. In contrast, the forest floor released moderate amounts of $\mathrm{NH}_{4}{ }^{+}$comparable to that released in the control. The lower nutrient supply under the forest floor amendment suggests a more steady and gradual release due to its more recalcitrant organic matter. With application rates much lower than that of the sludges, the forest floor provided $\mathrm{N}$ in a chemical form that is more adapted to white spruce nutrition (i.e., $\mathrm{NH}_{4}{ }^{+}$).

Despite differences in their chemical structure and nutrient supplies, sludge and forest floor amendments had similar effects on foliar nutrition and tree growth. Both sludge and forest floor treatments enhanced white spruce growth in the second year of the experiment, which is likely due to increased nutrient availability and improved growing conditions (i.e., moisture, rooting ability) in comparison to the control. However, given the size of the experiment and the lack of comparable studies in the published literature, these results would need to be confirmed under a larger range of site conditions.

Septic tank sludge could be a viable alternative to natural forest floor amendments on disturbed soils, including mining sites, by providing essential nutrients and promoting seedling growth. Land application for soil reclamation could also contribute to reducing greenhouse gas emissions associated with landfilling or incineration of organic residual materials. Although sludge availability is not likely to pose a problem, issues related to sludge transportation need to be addressed. Designing soil reclamation strategies that involve a single application of large doses of high-quality sludge may help to avoid high costs associated with sludge transportation to remote forested sites. However, risks associated with such high sludge doses also need to be evaluated, and sludge stabilisation optimised for this purpose.

\section{Acknowledgements}

This work was supported by the Natural Sciences and Engineering Research Council of Canada (NSERC, RDCPJ Grant 450412-13) and the Chaire industrielle CRSNGUQAT-UQAM en aménagement forestier durable (Chaire AFD). We are grateful to Marc-Olivier Hamelin, Hannah Brais-Harvey, Aurore Lucas, and Alfred Coulomb for field assistance, and to Jacinthe RicardPiché, Hélène Lalande, Dominique Bélanger, Julien Arsenault, and Brett Feland for laboratory work.

\section{References}

Agriculture and Agri-Food Canada. 2012. Soil landscapes of Canada. [Online]. Available from http://sis.agr.gc.ca/cansis/ publications/maps/slc/1m/v1/index.html [8 Mar. 2017].

Baldock, J.A., Oades, J.M., Nelson, P.N., Skene, T.M., Golchin, A., and Clarke, P. 1997. Assessing the extent of decomposition of 
natural organic materials using solid-state ${ }^{13} \mathrm{C}$ NMR spectroscopy. Aust. J. Soil Res. 35: 1061. doi:10.1071/S97004.

Bartoszek, M., Polak, J., and Sułkowski, W.W. 2008. NMR study of the humification process during sewage sludge treatment. Chemosphere, 73: 1465-1470. doi:10.1016/j.chemosphere. 2008.07.051. PMID:18774587.

Bell, R.W. 2006. Land restoration: principles. Pages 978-981 in R. Lal, ed. Encyclopedia of soil science. CRC Press, Boca Raton, FL, USA.

Bernal, M.P., Paredes, C., Sánchez-Monedero, M.A., and Cegarra, J. 1998. Maturity and stability parameters of composts prepared with a wide range of organic wastes. Bioresour. Technol. 63: 91-99. doi:10.1016/S0960-8524(97)00084-9.

Bernal, M.P., Alburquerque, J.A., and Moral, R. 2009. Composting of animal manures and chemical criteria for compost maturity assessment. A review. Bioresour. Technol. 100: 5444-5453. doi:10.1016/j.biortech.2008.11.027. PMID:19119002.

Bilodeau-Gauthier, S., Paré, D., Messier, C., and Bélanger, N. 2013. Root production of hybrid poplars and nitrogen mineralization improve following mounding of boreal Podzols. Can. J. For. Res. 43: 1092-1103. doi:10.1139/cjfr-2013-0338.

Brais, S., Camiré, C., and Paré, D. 1995. Impacts of whole-tree harvesting and winter windrowing on soil $\mathrm{pH}$ and base status of clayey sites of northwestern Quebec. Can. J. For. Res. 25: 997-1007. doi:10.1139/x95-108.

Brais, S., Paré, D., Camiré, C., Rochon, P., and Vasseur, C. 2002. Nitrogen net mineralization and dynamics following wholetree harvesting and winter windrowing on clayey sites of northwestern Quebec. For. Ecol. Manag. 157: 119-130. doi:10.1016/S0378-1127(00)00643-5.

Bramryd, T. 2002. Impact of sewage sludge application on the long-term nutrient balance in acid soils of scot pine (Pinus sylvestris, L.) forests. Water. Air. Soil Pollut. 140: 381-399. doi:10.1023/A:1020142311652.

Bremner, J. 1996. Nitrogen-total. Pages 1035-1122 in Methods of soil analysis, Part 3. Chemical methods, 3rd ed. Soil Science Society of America and American Society of Agronomy, Madison, WI, USA.

Caricasole, P., Provenzano, M.R., Hatcher, P.G., and Senesi, N. 2011. Evolution of organic matter during composting of different organic wastes assessed by CPMAS ${ }^{13} \mathrm{C}$ NMR spectroscopy. Waste Manag. 31: 411-415. doi:10.1016/j.wasman. 2010.09.020. PMID:20965714.

Cavaleri, M.A., Gilmore, D.W., Mozaffari, M., Rosen, C.J., and Halbach, T.R. 2004. Hybrid poplar and forest soil response to municipal and industrial by-products: a greenhouse study. J. Environ. Qual. 33: 1055-1061. doi:10.2134/jeq2004.1055. PMID:15224944.

Correll, D.L. 1998. The role of phosphorus in the eutrophication of receiving waters: a review. J. Environ. Qual. 27: 261. doi:10.2134/jeq1998.00472425002700020004x.

DesRochers, A., and Tremblay, F. 2009. The effect of root and shoot pruning on early growth of hybrid poplars. For. Ecol. Manag. 258: 2062-2067. doi:10.1016/j.foreco.2009.07.059.

Dumbrell, I.C., and McGrath, J.F. 2002. Biosolids produce significant increases in growth and nutrient status in Western Australian pine plantation without contamination of groundwater. Pages 19-20 in Proceedings: biosolids specialty conference. Australian Water Association, Artarmon, New South Wales, Sydney, Australia.

Edwards, N.T. 1982. The use of soda-lime for measuring respiration rates in terrestrial systems. Pedobiologia, 23: 321-330.

Elferjani, R., DesRochers, A., and Tremblay, F. 2014. Effects of mixing clones on hybrid poplar productivity, photosynthesis and root development in northeastern Canadian plantations. For. Ecol. Manag. 327: 157-166. doi:10.1016/j. foreco.2014.05.013.
Environnement Canada. 2010. Canadian climate normals 19712000 station data. [Online]. Available from http://climat.meteo. gc.ca/climate_normals/results_f.html?stnID=5988\&radius= 200\&proxSearchType $=$ coordinates\&degreesNorth $=48 \&$ minutes North=44\&secondsNorth=\&degreesWest=79\&minutesWest= $40 \&$ secondsWest $=\&$ proxSubmit $=$ go\&dCode $=1$ [ 6 May 2015].

Epstein, E. 2002. Plant nutrients. Pages 29-38 in Land application of sewage sludge and biosolids. CRC Press, Boca Raton, FL, USA. [Online]. Available from https://www.taylorfrancis. com/books/9781420032116 [6 Feb. 2014].

Fleming, R.L., Powers, R.F., Foster, N.W., Kranabetter, J.M., Scott, D.A., Ponder Jr, F., Berch, S., Chapman, W.K., Kabzems, R.D., Ludovici, K.H., Morris, D.M., Page-Dumroese, D.S., Sanborn, P.T., Sanchez, F.G., Stone, D.M., and Tiarks, A.E. 2006. Effects of organic matter removal, soil compaction, and vegetation control on 5-year seedling performance: a regional comparison of long-term soil productivity sites. Can. J. For. Res. 36: 529-550. doi:10.1139/x05-271.

Fredriksen, R.L., Moore, D.G., and Norris, L.A. 1973. The impact of timber harvest, fertilization, and herbicide treatment on streamwater quality in western Oregon and Washington. Pages 283-313 in B. Bernier and C.H. Winget, eds. Forest soils and forest land management. Les presses de l'université Laval, Laval university, Quebec, QC, Canada.

Gaulke, L.S., Henry, C.L., and Brown, S.L. 2006. Nitrogen fixation and growth response of Alnus Rubra following fertilization with urea or biosolids. Sci. Agric. 63: 361-369. doi:10.1590/S0103-90162006000400007.

Ghose, M. 2004. Effect of opencast mining on soil fertility. J. Sci. Ind. Res. 63: 1006-1009.

Gibbs, P.A., Chambers, B.J., Chaudri, A.M., McGrath, S.P., Carlton-Smith, C.H., Bacon, J.R., Campbell, C.D., and Aitken, M.N. 2006. Initial results from a long-term, multi-site field study of the effects on soil fertility and microbial activity of sludge cakes containing heavy metals. Soil Use Manag. 22: 11-21. doi:10.1111/j.1475-2743.2006.00003.x.

Giusti, L. 2009. A review of waste management practices and their impact on human health. Waste Manag. 29: 22272239. doi:10.1016/j.wasman.2009.03.028. PMID:19401266.

Grey, M., and Henry, C. 2002. Phosphorus and nitrogen runoff from a forested watershed fetilized with biosolids. J. Environ. Qual. 31: 926-936. doi:10.2134/jeq2002.9260. PMID:12026097.

Hallett, R.A., Bowden, W.B., and Smith, C.T. 1999. Nitrogen dynamics in forest soils after municipal sludge additions. Water Air Soil Pollut. 112: 259-278. doi:10.1023/A:1005086413282.

Harrison, R.B., Henry, C.L., Xue, D., Canary, J., Leonard, P., and King, R. 2000. The fate of metals in land application systems. Digestion, 3: 49-53.

Haynes, R.J., Murtaza, G., and Naidu, R. 2009. Chapter 4: Inorganic and organic constituents and contaminants of biosolids. Pages 165-267 in Advances in agronomy. Elsevier, Burlington, VT, USA. [Online]. Available from http:// linkinghub.elsevier.com/retrieve/pii/S0065211309040048 [9 Dec. 2015].

Holm, B., and Heinsoo, K. 2013. Influence of composted sewage sludge on the wood yield of willow short rotation coppice. An Estonian case study. Environ. Prot. Eng. 39: 17-32. doi:10.5277/epe130102.

Islas-Espinoza, M., Solís-Mejía, L., and Esteller, M.V. 2013. Phosphorus release kinetics in a soil amended with biosolids and vermicompost. Environ. Earth Sci. 71: 1441-1451. doi:10.1007/s12665-013-2549-y.

Jimenez, J., Vedrenne, F., Denis, C., Mottet, A., Déléris, S., Steyer, J.-P., and Cacho Rivero, J.A. 2013. A statistical comparison of protein and carbohydrate characterisation methodology applied on sewage sludge samples. Water Res. 47: 1751-1762. doi:10.1016/j.watres.2012.11.052. PMID:23357791. 
Johnson, D.W., Cole, D.W., Van Miegroet, H., and Horng, F.W. 1986. Factors affecting anion movement and retention in four forest soils. Soil Sci. Soc. Am. J. 50: 776. doi:10.2136/ sssaj1986.03615995005000030042x.

Kao, P.H., Huang, C.C., and Hseu, Z.Y. 2006. Response of microbial activities to heavy metals in a neutral loamy soil treated with biosolid. Chemosphere, 64: 63-70. doi:10.1016/j. chemosphere.2005.11.039. PMID:16403552.

Keeler, C., and Maciel, G.E. 2000. ${ }^{13} \mathrm{C}$ NMR spectral editing of humic material. J. Mol. Struct. 550-551: 297-305. doi:10.1016/S0022-2860(00)00501-9.

Keith, H., and Wong, S. 2006. Measurement of soil $\mathrm{CO}_{2}$ efflux using soda lime absorption: both quantitative and reliable. Soil Biol. Biochem. 38: 1121-1131. doi:10.1016/j.soilbio.2005. 09.012 .

Khan, M., and Scullion, J. 2002. Effects of metal (Cd, Cu, Ni, Pb or $\mathrm{Zn}$ ) enrichment of sewage-sludge on soil micro-organisms and their activities. Appl. Soil Ecol. 20: 145-155. doi:10.1016/ S0929-1393(02)00018-5.

Kögel-Knabner, I. 1997. ${ }^{13} \mathrm{C}$ and ${ }^{15} \mathrm{~N}$ NMR spectroscopy as a tool in soil organic matter studies. Geoderma, 80: 243-270. doi:10.1016/S0016-7061(97)00055-4.

Kögel-Knabner, I. 2002. The macromolecular organic composition of plant and microbial residues as inputs to soil organic matter. Soil Biol. Biochem. 34: 139-162. doi:10.1016/ S0038-0717(01)00158-4.

Kronzucker, H.J., Siddiqi, M.Y., and Glass, A.D.M. 1997. Conifer root discrimination against soil nitrate and the ecology of forest succession. Nature, 385: 59-61. doi:10.1038/385059a0.

Kuzyakov, Y., Friedel, J., and Stahr, K. 2000. Review of mechanisms and quantification of priming effects. Soil Biol. Biochem. 32: 1485-1498. doi:10.1016/S0038-0717(00)00084-5.

Larcheveque, M., Desrochers, A., and Larocque, G.R. 2011. Comparison of manure compost and mineral fertilizer for hybrid poplar plantation establishment on boreal heavy clay soils. Ann. For. Sci. 68: 849-860. doi:10.1007/s13595-011-0081-3.

Larney, F.J., and Angers, D.A. 2012. The role of organic amendments in soil reclamation: a review. Can. J. Soil Sci. 92: 19-38. doi:10.4141/cjss2010-064.

Lessa, A.S.N., Anderson, D.W., and Chatson, B. 1996. Cultivation effects on the nature of organic matter in soils and water extracts using $\mathrm{CP} / \mathrm{MAS}{ }^{13} \mathrm{C}$ NMR spectroscopy. Plant Soil, 184: 207-217. doi:10.1007/BF00010450.

Martínez, F., Cuevas, G., Calvo, R., and Walter, I. 2003. Biowaste effects on soil and native plants in a semiarid ecosystem. J. Environ. Qual. 32: 472-479. doi:10.2134/jeq2003.4720.

McDowell, R., Sharpley, A., Brookes, P., and Poulton, P. 2001. Relationship between soil test phosphorus and phosphorus release to solution. Soil Sci. 166: 137-149. doi:10.1097| 00010694-200102000-00007.

McLaren, R.G., Clucas, L.M., Speir, T.W., and van Schaik, A.P. 2007. Distribution and movement of nutrients and metals in a Pinus radiata forest soil following applications of biosolids. Environ. Pollut. 147: 32-40. doi:10.1016/j.envpol.2006.08.027.

MDDEP (Ministère du développement durable, de l'environnement et des parcs). 2012. Guide sur le recyclage des matères résiduelles fertilisantes : Critères de référence et normes réglementaires, Québec, ministère du Développement durable, de l'Environnement et des Parcs. 170 p.

Menta, C., Conti, F.D., Pinto, S., Leoni, A., and Lozano-Fondón, C. 2014. Monitoring soil restoration in an open-pit mine in northern Italy. Appl. Soil Ecol. 83: 22-29. doi:10.1016/j. apsoil.2013.07.013.

Miltner, A., Kindler, R., Knicker, H., Richnow, H.-H., and Kästner, M. 2009. Fate of microbial biomass-derived amino acids in soil and their contribution to soil organic matter. Org. Geochem. 40: 978-985. doi:10.1016/j.orggeochem.2009.06.008.
Monteith, J.L., Szeicz, G., and Yabuki, K. 1964. Crop photosynthesis and the flux of carbon dioxide below the canopy. J. Appl. Ecol. 1: 321. doi:10.2307/2401316.

Moritsuka, N., Matsuoka, K., Matsumoto, S., Masunaga, T., Matsui, K., and Wakatsuki, T. 2006. Effects of the application of heated sewage sludge on soil nutrient supply to plants. Soil Sci. Plant Nutr. 52: 528-539. doi:10.1111/j.1747-0765. 2006.00062.x.

Moukoumi, J., Farrell, R.E., Van Rees, K.J.C., Hynes, R.K., and Bélanger, N. 2012. Intercropping Caragana arborescens with Salix miyabeana to satisfy nitrogen demand and maximize growth. BioEnergy Res. 5: 719-732. doi:10.1007/s12155012-9181-7.

Preston, C.M. 1996. Environmental NMR: solid-state methods. Pages 29-42 in R.K. Harris and R.L. Wasylishen, eds. eMagRes. John Wiley \& Sons, Ltd, Chichester, UK. [Online]. Available from http://doi.wiley.com/10.1002/9780470034590. emrstm1338 [22 Oct. 2015].

Prescott, C.E., Maynard, D.G., and Laiho, R. 2000. Humus in northern forests: Friend or foe? For. Ecol. Manag. 133: 23-36. doi:10.1016/S0378-1127(99)00295-9.

Pritchard, D.L., Penney, N., McLaughlin, M.J., Rigby, H., and Schwarz, K. 2010. Land application of sewage sludge (biosolids) in Australia: risks to the environment and food crops. Water Sci. Technol. 62: 48-57. doi:10.2166/wst.2010.274. PMID:20595753.

Quideau, S.A., Chadwick, O.A., Benesi, A., Graham, R.C., and Anderson, M.A. 2001. A direct link between forest vegetation type and soil organic matter composition. Geoderma, 104: 41-60. doi:10.1016/S0016-7061(01)00055-6.

R Core Team. 2015. R: a language and environment for statistical computing. R Foundation for Statistical Computing, Vienna, Austria. [Online]. Available from https://www.R-project.org/.

Robertson, G.P., and Groffman, P.M. 2015. Nitrogen transformations. Pages 421-446 in E.A. Paul, ed. Soil microbiology, ecology and biochemistry. 4th ed. Academic Press, Burlington, MA, USA. [Online]. Available from http://linkinghub.elsevier. com/retrieve/pii/B9780124159556000141 [14 Mar. 2016].

Robinson, M.B., Polglase, P.J., and Weston, C.J. 2002. Loss of mass and nitrogen from biosolids applied to a pine plantation. Aust. J. Soil Res. 40: 1027. doi:10.1071/SR01088.

Robitaille, A., and Saucier, J.-P. 1998. Paysages régionaux du Québec méridional. Les Publications du Québec, Québec, QC, USA.

Rowell, D. 1996. State forests' biosolids research and demonstration program: a status report. Organic Waste Recycling Unit, NSW Agriculture, Sydney, Australia.

Rowell, D.M., Prescott, C.E., and Preston, C.M. 2001. Decomposition and nitrogen mineralization form biosolids and other organic materials: relationship with initial chemistry. J. Environ. Qual. 30: 1401-1410. doi:10.2134/jeq2001. 3041401x. PMID:11476519.

Rydgren, K., and Hestmark, G. 1997. The soil propagule bank in a boreal old-growth spruce forest: changes with depth and relationship to aboveground vegetation. Can. J. Bot. 75: 121-128. doi:10.1139/b97-014.

Sahrawat, K.L. 2008. Factors affecting nitrification in soils. Commun. Soil Sci. Plant Anal. 39: 1436-1446. doi:10.1080/ 00103620802004235.

Samaras, V., Tsadilas, C.D., and Stamatiadis, S. 2008. Effects of repeated application of municipal sewage sludge on soil fertility, cotton yield, and nitrate leaching. Agron. J. 100: 477. doi:10.2134/agronj2007.0162.

Schmidt, E.L. 1982. Nitrification in soil. Pages 253-267 in F.J. Stevenson, ed. Nitrogen in agricultural soils. ASA, CSSA, and SSSA, Madison, WI, USA. [Online]. Available from https://dl.sciencesocieties.org/publications/books/abstracts/ agronomymonogra/nitrogeninagrics/253 [2 Feb. 2016]. 
Selivanovskaya, S.Y., and Latypova, V.Z. 2006. Effects of composted sewage sludge on microbial biomass, activity and pine seedlings in nursery forest. Waste Manag. 26: 12531258. doi:10.1016/j.wasman.2005.09.018. PMID:16307873.

Sheoran, V., Sheoran, A.S., and Poonia, P. 2010. Soil reclamation of abandoned mine land by revegetation: a review. Int. J. Soil Sediment Water, 3: Article 13.

Singh, K.P., Ghoshal, N., and Singh, S. 2009. Soil carbon dioxide flux, carbon sequestration and crop productivity in a tropical dryland agroecosystem: influence of organic inputs of varying resource quality. Appl. Soil Ecol. 42: 243-253. doi:10.1016/j.apsoil.2009.04.005.

Singh, R.P., and Agrawal, M. 2008. Potential benefits and risks of land application of sewage sludge. Waste Manag. 28: 347-358. doi:10.1016/j.wasman.2006.12.010. PMID:17320368.

Singh, R.P., Ibrahim, M.H., and Hashim, R. 2011. Land application of sewage sludge: physicochemical and microbial response. Rev. Environ. Contam. Toxicol. 214: 41-61. doi:10.1007/978-1-4614-0668-6_3.

Smith, M.T.E., Smernik, R.J., Merrington, G., and Tibbett, M. 2008. Changes in sewage sludge carbon forms along a treatment stream. Chemosphere, 72: 981-985. doi:10.1016/j. chemosphere.2008.02.062. PMID:18472133.

Smith, S.E., and Read, D.J. 2009. Mycorrhizal symbiosis. 3rd ed., Repr. Elsevier/Academic Press, Amsterdam, the Netherlands.

Soil classification working group. 1998. The Canadian system of soil classification. 3rd ed. Agriculture Canada, Ottawa, ON, Canada.

Soriano-Disla, J.M., Navarro-Pedreño, J., and Gómez, I. 2010. Contribution of a sewage sludge application to the shortterm carbon sequestration across a wide range of agricultural soils. Environ. Earth Sci. 61: 1613-1619. doi:10.1007/ s12665-010-0474-x.

Ste-Marie, C., and Paré, D. 1999. Soil, pH and N availability effects on net nitrification in the forest floors of a range of boreal forest stands. Soil Biol. Biochem. 31: 1579-1589. doi:10.1016/S0038-0717(99)00086-3.

Torri, S.I., Corrêa, R.S., and Renella, G. 2014a. Soil carbon sequestration resulting from biosolids application. Appl. Environ. Soil Sci. 2014: 1-9. doi:10.1155/2014/821768.
Torri, S.I., Corrêa, R.S., Renella, G., Perelomov, L., and Valdecantos, A. 2014b. Biosolids soil application: agronomic and environmental implications 2013. Appl. Environ. Soil Sci. 2014: 1-3. doi:10.1155/2014/314730.

Varela, S.A., Gobbi, M.E., and Laos, F. 2011. Can biosolids compost improve, in the short term, native vegetation and soils fertility in burned Nothofagus pumilio forest in Patagonia, Argentina? Bosque Valdivia, 32: 267-278. doi:10.4067| S0717-92002011000300008.

Veillette, J., Bergeron, Y., Gaudreau, L., Miron, F., and Drainville, G. 2000. Abitibi-Témiscamingue: de l'emprise des glaces à un foisonnement d'eau et de vie: 10000 ans d'histoire. Sainte-Foy, Québec, QC, Canada.

Vitousek, P.M., and Howarth, R. 1991. Nitrogen limitation on land and in the sea: how can it occur? Biogeochemistry, 13: 87-115. doi:10.1007/BF00002772.

Wang, H., Magesan, G.N., Kimberley, M.O., Payn, T.W., Wilks, P.J., and Fisher, C.R. 2004. Environmental and nutritional responses of a Pinus radiata plantation to biosolids application. Plant Soil, 267: 255-262. doi:10.1007/ s11104-005-0107-4.

Weetman, G.F., and Nykvist, N.B. 1963. Some MOR humus, regeneration and nutrition problems and practices in North Sweden. For. Chron. 39: 188-198. doi:10.5558/ tfc39188-2.

Western Ag Innovations Inc. 2010. Plant root simulator (PRS $\left.{ }^{\mathrm{TM}}\right)$ operations manual. 6th ed. Western Ag Innovations Inc., Saskatoon, SK, Canada.

Zbytniewski, R., and Buszewski, B. 2005. Characterization of natural organic matter (NOM) derived from sewage sludge compost. Part 1: chemical and spectroscopic properties. Bioresour. Technol. 96: 471-478. doi:10.1016/j.biortech. 2004.05.018. PMID:15491829.

Zbytniewski, R., Kosobucki, P., Kowalkowski, T., and Buszewski, B. 2002. The comparison study of compost and natural organic matter samples. Environ. Sci. Pollut. Res. 9: 68-74. doi:10.1007| BF02987429.

Zilbilske, L.M. 1994. Carbon mineralization. Pages 835-863 in S.H. Mickelson, ed. Methods of soil analysis, Part 2. Microbiological and biochemical properties. Soil Science Society of America Inc., Madison, WI, USA. 